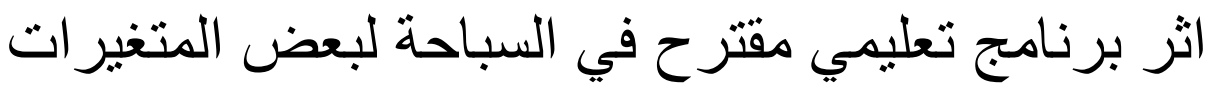

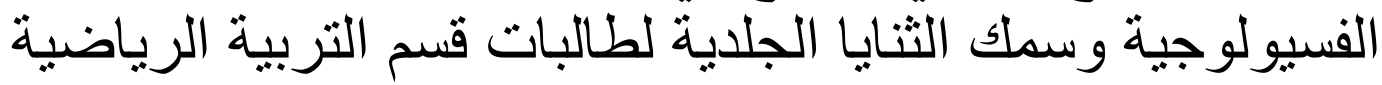
في كلية التربية

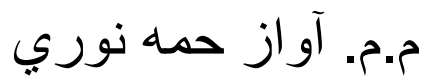 \\ جامعة صلاح الدين / كلية التربية الرياضية
}

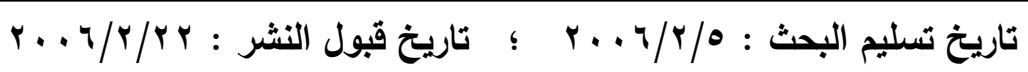

هدف البحث في التعرف على اثر البرنامج التعليمي المقترح في السباحة على بعض

المتغيرات الفسيولوجية (الحد الاقصى لاستهلاك الاوكسجين vo2max ،ضغط الدم ،النبض) و سمك الثنايـا الجلديـة لطالبـات قسم التربيـة الرياضية ، كلية التربيـة ،وتكونت عينة البحث من طالبات المرحلة الاولى بقسم التربية الرياضية / جامعة كويه حيث تم اختبار (0 (1) طالبة من اصل (rV) طالبا وذلك لالتزامهن بالدوام وتكافؤهن وتجانسهن بالمتغيرات البدنية، ومن اجل قياس المتغيرات الفسيولوجية قيد البحث فقد لجأت الباحثة الى استخدام الاختبارات الاتية : قياس معدل القلب لقيـاس النبض ،قيـاس ضـغط الـدم ،اختبـار استراند على الدراجـة الارجومتريـة VO2max لاستخدمها في التتبؤ بالحد الاقصى لاستهلاك الاوكسجين ومن اجل قياس سمك الثنايا الجلدية ، فقد استخدمت الباحثة المواقع التي تعكس النسبة الكلية للدهن في النساء وهي ذات الثثلاث رؤوس العضدية ،فوق الحرقفة ،الفخذ . كما تم استخدام المعالجات الاحصائية الاتيـة (الوسط الحسابي ،الانحراف المعياري ، اختبار t) من اجل التوصل الى النتائج التي كان اهمها ان البرنامج التعليمي المقترح ذو تأثثر ايجابي على المتغيرات الفسيولوجية وسمك الثنايا الجلدية، كذلك وجود فروق ذات دلالة معنوية بين الاختبارين القبلي والبعدي لاختبار الحد الاقصى لاستهلالك الاوكسجين vo2max وقياس ضغط الدم الانقباضي والانبساطي والنبض ولصالح الاختبار البعدي 


\title{
The Impact of a Proposed Swimming Program on Some Physiological Variables And Skin Folders of Female Students at Physical Education Department College of Education
}

\author{
Awaz Hama Noori \\ University of Slahaldeen - College of Sport Education
}

\section{Abstract:}

The study aims at identifying the impact of the swimming proposed program on some physiological variables $\left(\mathrm{VO}_{2} \max\right.$, blood pressure, pulse) and the thickness of skin folders for female students at the Department of Physical Education, College of Education. The study sample consisted of freshman female students, first class at the Department of Physical Education / Koya University. Fifteen female students out of (27) were selected for their equivalence in physical variables. To measure physiological variables, the researcher has used the following tests: heart ratio to measure pulse, blood pressure measurement and Strand test on the bicycle argometric to be used in predicting $\mathrm{VO}_{2}$ max. To measure skinfold thickness, the researcher has used the locations reflecting the total ratio of fat in women, including triceps, supraspinale. Mean, standard deviation and t-test were used as statistical means to derive the results. The proposed educational program has a positive impact on physiological variables and thickness of skin folds. There were significant differences between the pre and post tests for $\mathrm{VO}_{2}$ max and systolic and diastolic blood pressures and pulse for the favor of post-test. 
أولت معظم دول العالم ولاسيما في وقتتا الحاضر عناية خاصة بنمو الانسان وتربيته في

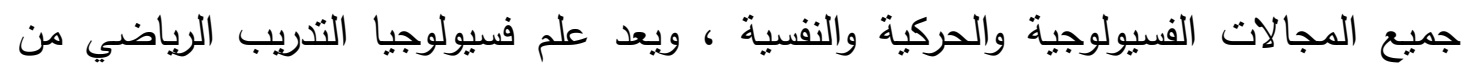

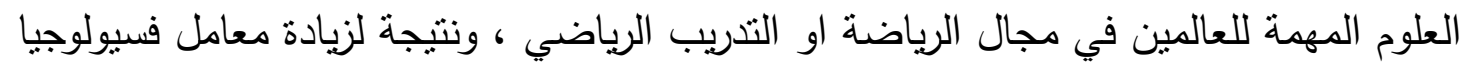
الرياضة خلال السنوات الاخيرة فقد استطاع الباحثون الحصول على المعلومات والحقائق الفسيولوجية المهمة والتي اسهمت في تطوير التدريب وتقتينه حتى يكون ملائما لقدرة الانسان

والتخطيط الجيد في وضع البرامج التعليمية والمبنية على اسس علمية بصورة منتظمة من الامور المهمة بالنسبة الى العاملين في هذا المجال حيث ان التخطيط السليم والمنظم في وضع الاهداف يكون ذو تأثير في تحقيق تلك الاهداف سواء اكانت اهداف بدنية او مهارية او

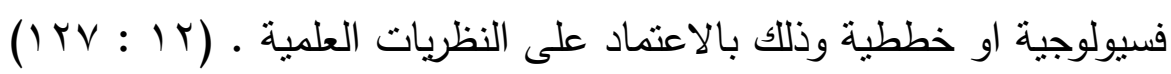

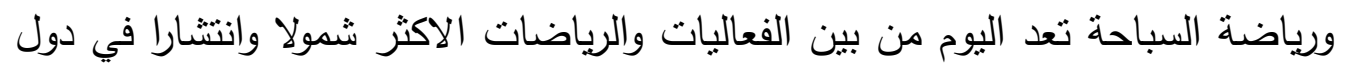

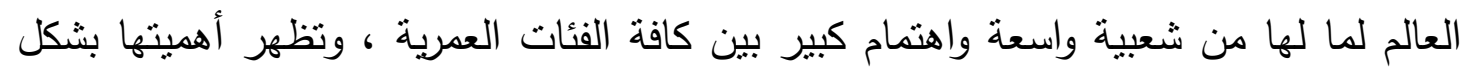

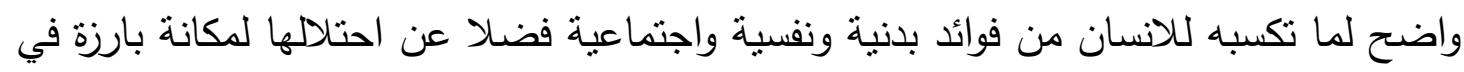

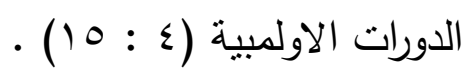

ونظراً لاهمية السباحة في حياة الفرد بغض النظر عن المرحلة العمرية والجنس وذلك

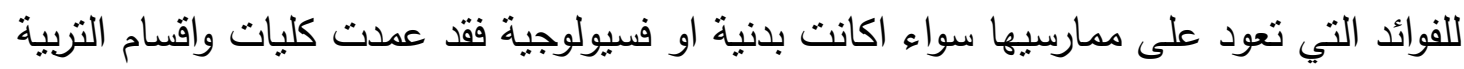

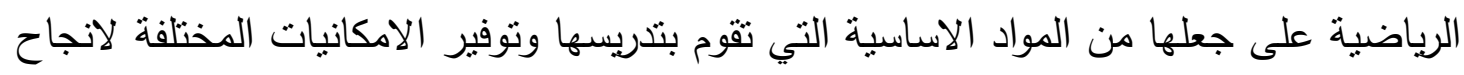

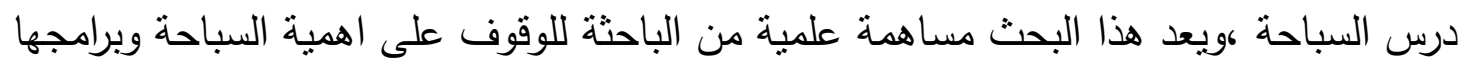

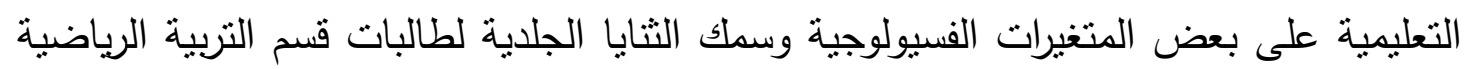
/كلية التربية.

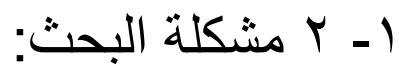

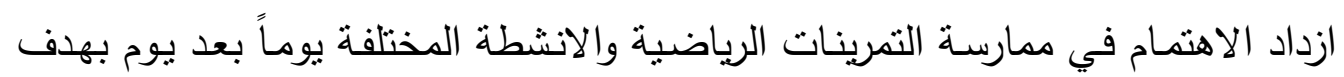

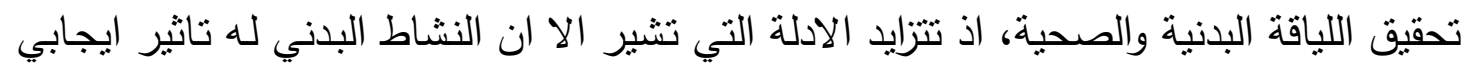

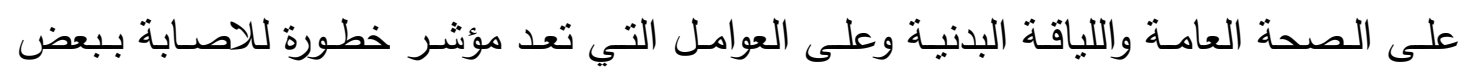

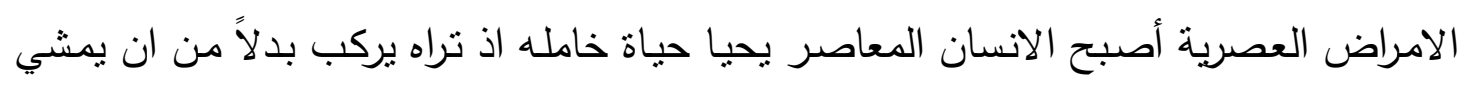

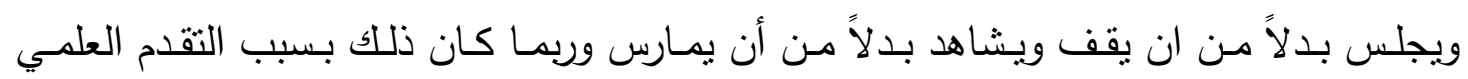

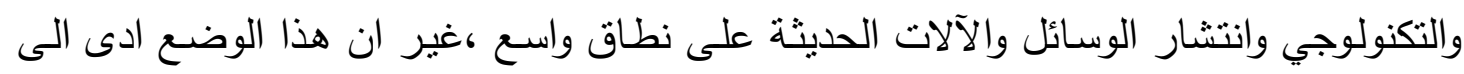


خفض الجهد البدني والحركي ونتيجة لذلك انتشرت العديد من الأمراض كالقلب والثرايين والسمنة وهي ما تعرف اليوم بامراض قله الحركة.وهن هنا جاء دور التربية الرياضية في الحد من انتشار هذه الأمراض من خلال أنشطتها المختلفة وبرامجها المتتوعة. ومن خلال عمل الباحثة في المجال الرياضي لاحظت ان معظم البرامج التعليمية التي

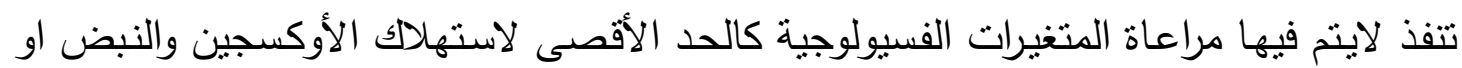
اثر تلك البرامج على سمك الثتايا الجلدية وهو من الامور المهمة جدا وخاصـة للنساء لتعلقها بالمظهر الخارجي لهن • وعليه ارتأت الباحث القيام بهذه الدراسـة من اجل معرفة اثر برنامج تعليمي مقترح في السباحة على بعض المتغيرات الفسيولوجية وسمك الثنايـا الجلديـة لطالبات السنة الدراسية الأولى بقسم التربية الرياضية في كلية التربية ـ وتلك هي مشكلة البحث .

$$
\text { ا -r هدفا البحث : يهدف البحث في التعرف على }
$$

اـ اثز البرنامج التعليمي المفترح في السباحة على بعض المتغيرات الفسيولوجية (الحد الاقصى لاستهالك الاوكسجين vo max ،ضغط الدم ،النبض) لطالبات قسم التربية الرياضية ، كلية التربية . r. اثر البرنامج التعليمي المقترح في السباحة على سمك الثنايا الجلديـة لطالبات قسم التربية الرياضية ، كلية التربية.

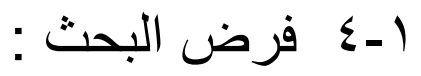

ا ـ توجـد فـروق ذات دلالــة معنويـة بـين الاختبـارين القبلـي والبعـدي فـي بعض المتغيـرات الفسيولوجية (الحد الاقصى لاستهلاك الاوكسجين vo 2 max ،ضغط الدم ،النبض) لطالبات قسم التربية الرياضية ، كلية التربية ولصالح الاختبار البعدي. r. توجد فروق ذات دلالـة معنويـة بين الاختبـارين القبلي والبعدي في سـك الثنايـا الجلديـة لطالبات قسم التربية الرياضية ، كلية التربية ولصالح الاختبار البعدي •

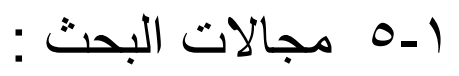

- المجال البشري: طالبات المرحلة الاولى بقسم التربية الرياضية / كلية التربية جامعة كويه.

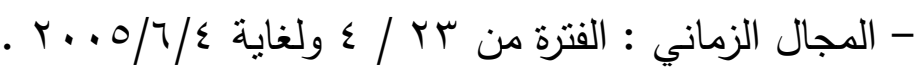
- المجال المكاني : المسبح الخاص في شارع الاطباء . 


$$
\text { 1 }
$$

1. الحـ الاقصى لاستهلاك الاوكسجين Vo (اقصى حجم للاوكسين المستهلك بالتز او المليلتر ويعد مؤشرا مهما لقياس الحالة الوظيفية

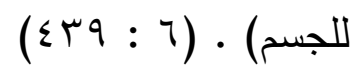

Y. ضغط الام : يعرفه ابو العلا احمد عبدالفتاح ومحمد صبحي حسانين (Y9V (19) على انه

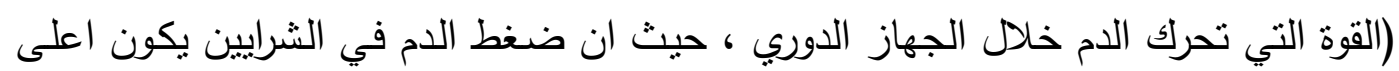

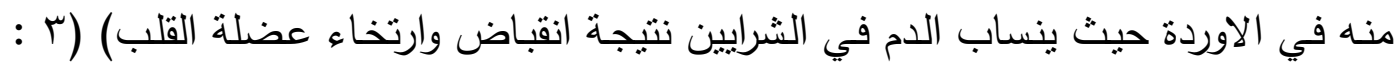
( ) $1 \mathrm{~V}$

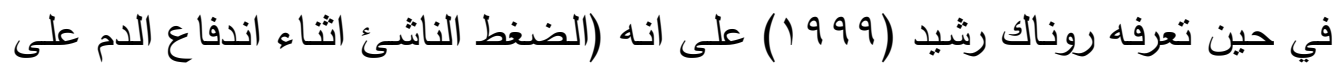

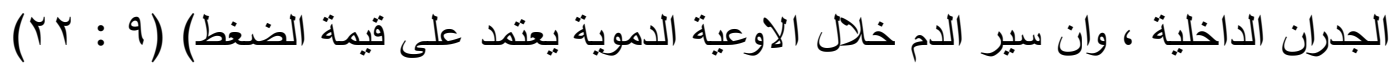

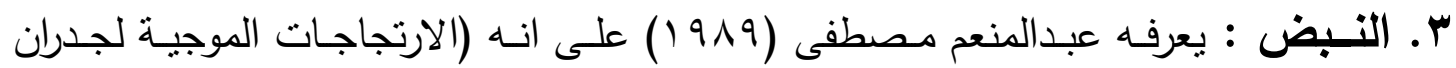

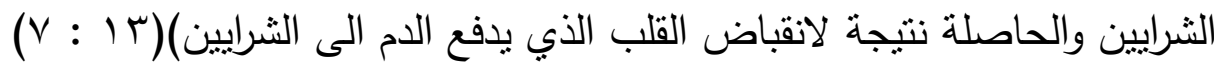

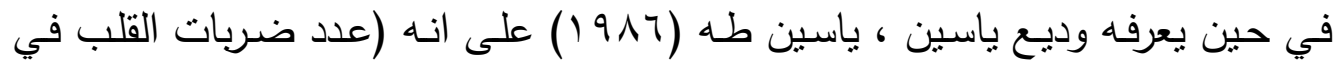

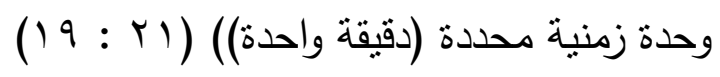

ع. سـكك الثنايـا الجلايـة : تعرفه آمال السيد الشامي نقلا عن موترام (910 (1) على انه (مركبـات الجسم مـن الـهون والتي تكون عـادة على شـكل مركبـات مـن الكليسيترول

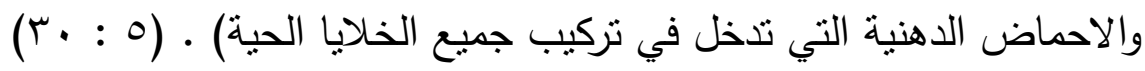

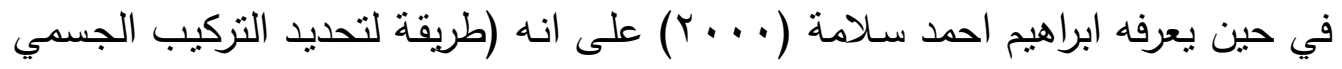

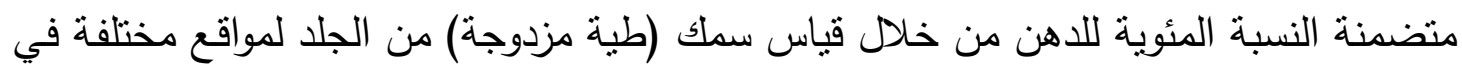

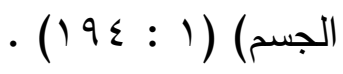

r - الاطار النظري و الدر اسات السابقة : الإر النظري :

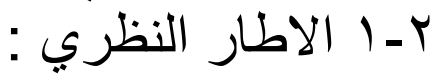

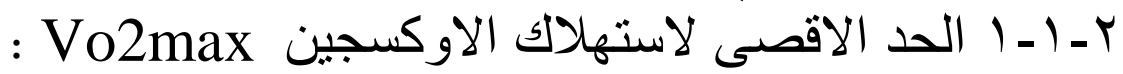
يعبـر الحـد الاقصى لاسـتهلالك الاوكسجين عـن مقدار كفــاءة عمليـات امتصاص لاص

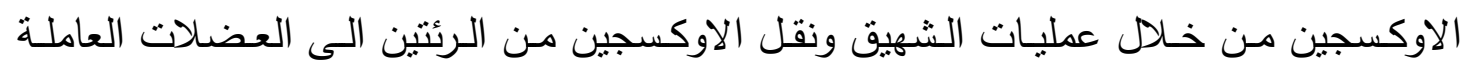

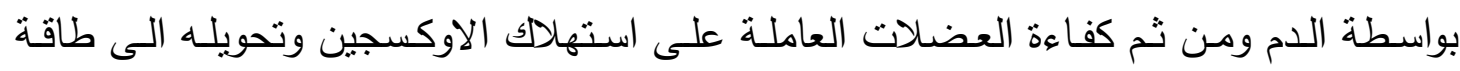

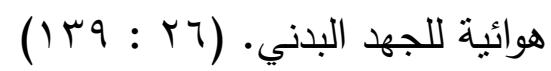


كما انه يعد احد القدرات الفسيولوجية التي تعبر عن قدرة الجسم على انتاج اكبر كمية من الطاقة الهوائية في الدقيقة الواحدة ، حيث ان زيادة استهلالك الاوكسجين يعني زيادة قدرة العضلة على انتاج الطاقة وبهذا الخصوص يشير كلا من (Donfrank \& Howly , 1992)

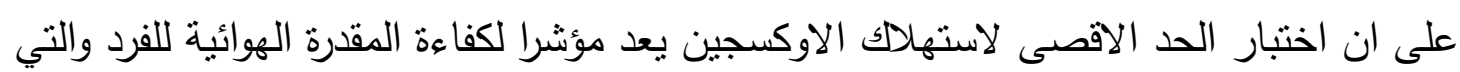

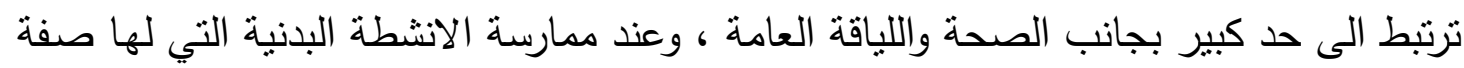
العمل الهوائي فان كمية الاوكسجين القصوى التي يمكن استهاكها خلال دقيقة واحدة هي التي لتئي

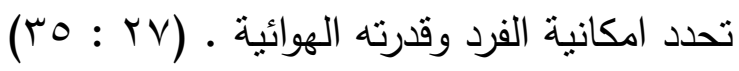

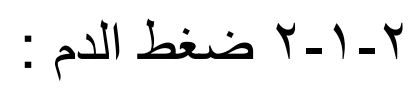

اختلف الخبراء والباحثين في مقادير الضغط الدموي الانقباضي والانبساطي في اثتاء

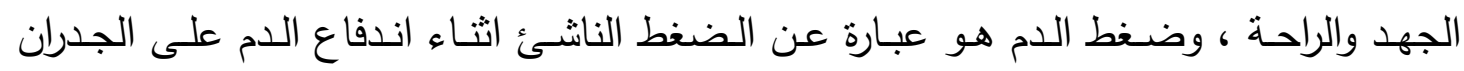

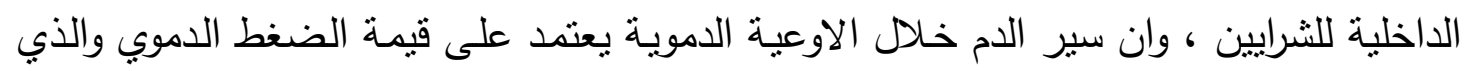

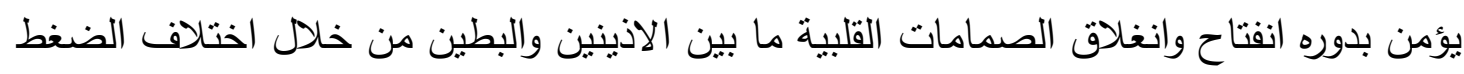

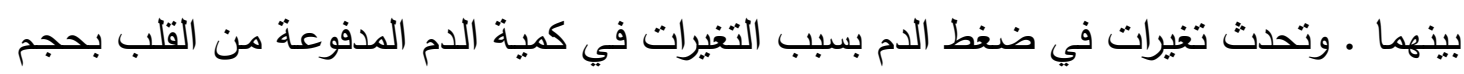

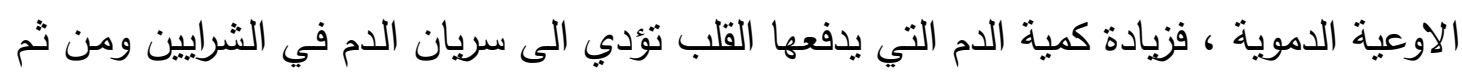

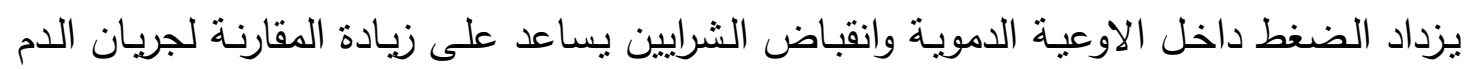

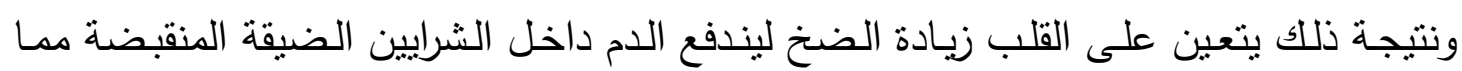

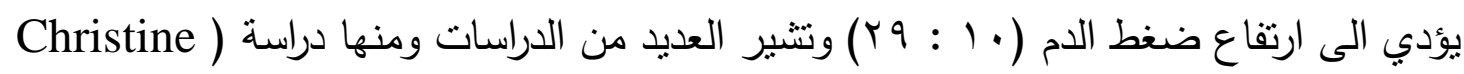

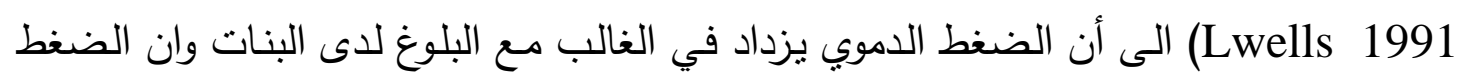

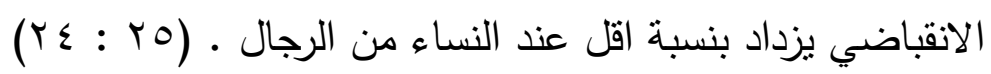

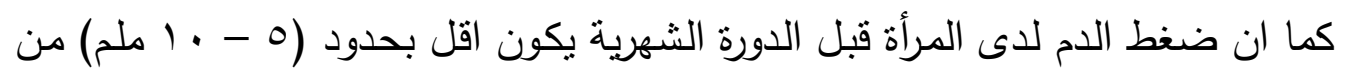
الرجل وبنفس العمر ولكن بعد الدورة فان ضغط الدم برتفع بصورة واضحة عما عليه عند الرجل

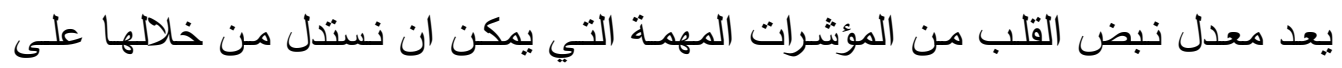

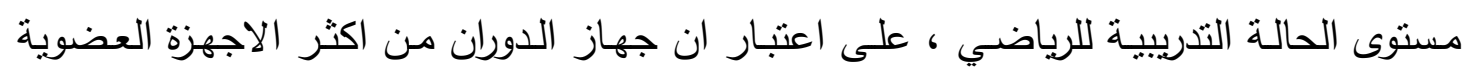

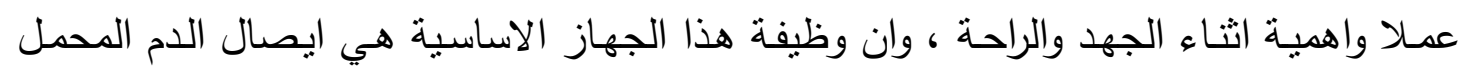

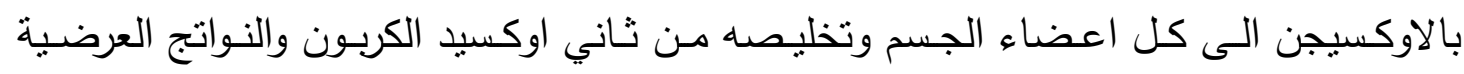

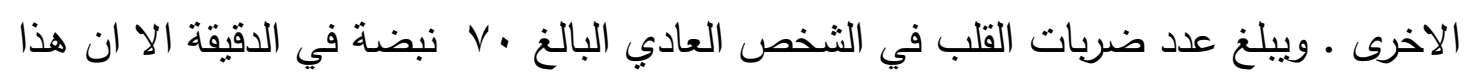


الرقم ليس ثابتا لدى الاثخاص جميعهم اذ ان الزيادة او النقصان لا تدل في الغالب على وجود

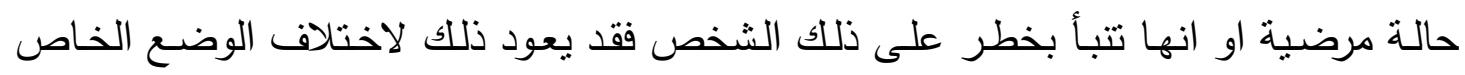

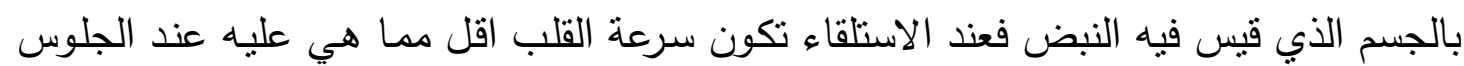

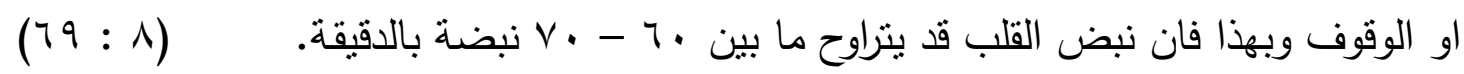

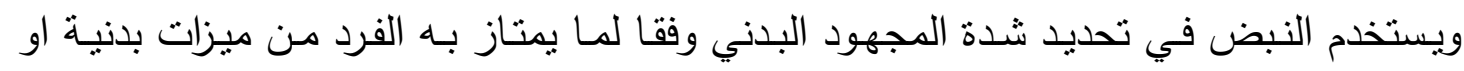

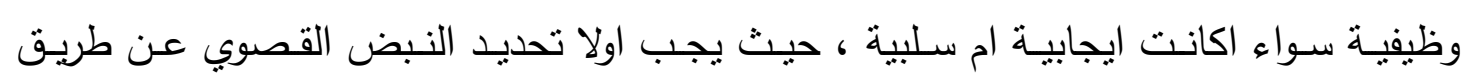

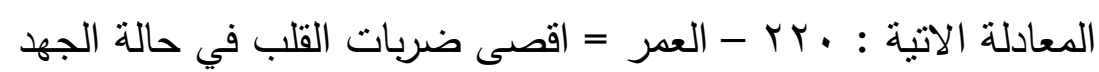

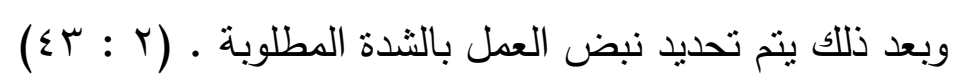

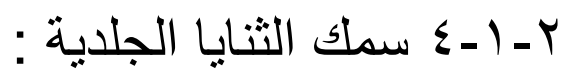

ينقسم الدهن الموجود بالجسم الى نوعين اساسيين هما الدهن الاساسي او الضروري

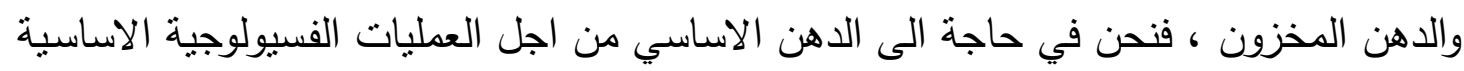

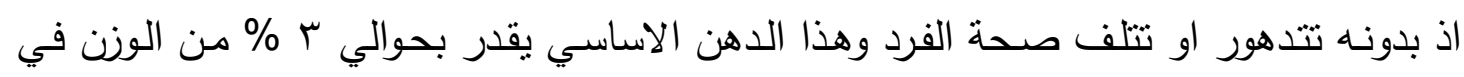

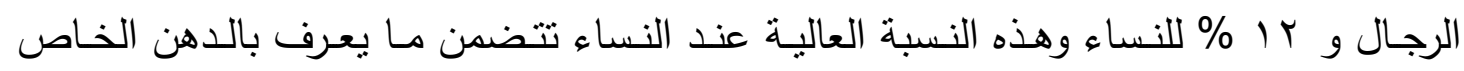
بالجنس كذلك الذي ينواجد في نسيج الصدر والرحم وغيره من الانسجة الدهينة للمرأة. امـا الدهن

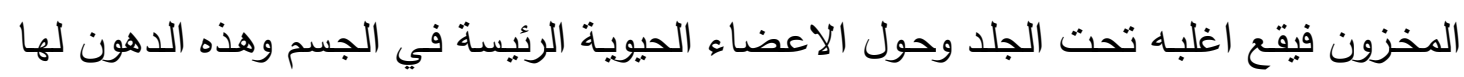
وظائف اساسية كالاحتفاظ بدرجة حرارة الجسم وبطانة ضد الجروح والرضوض والبه والصدمات الباء البدنية

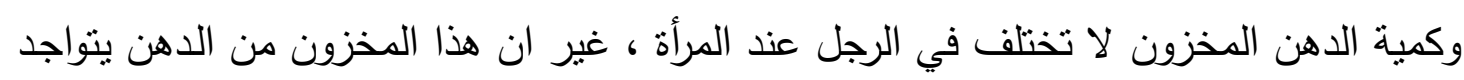

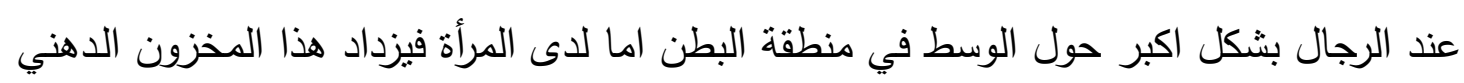

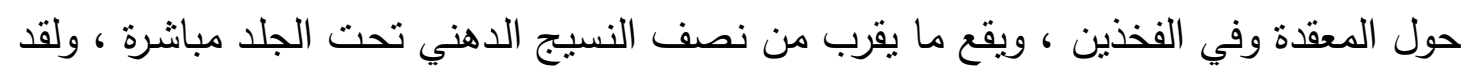

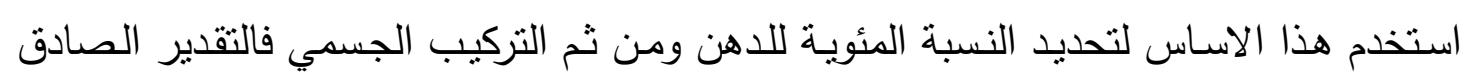

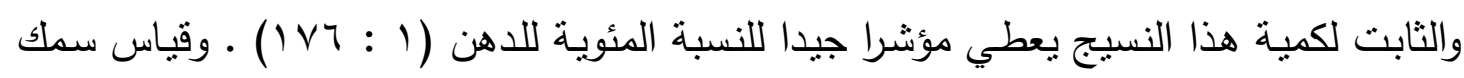

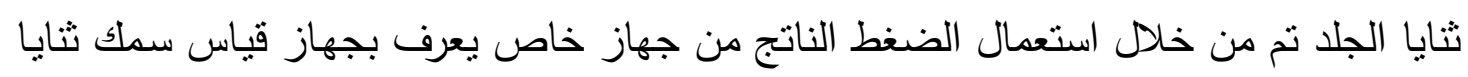
الجلد (Skin fold caliper) وفي هذه الطريقة يتم قياس هذا السمك من خلال عدة مواقع

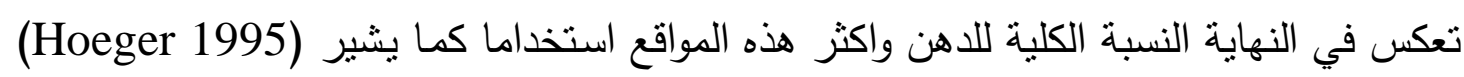

$$
\begin{aligned}
& \text { هي : } \\
& \text { ذات الثلاث الرؤوس العضدية ـ } \\
& \text { فوق الحرقفة . } \\
& (I r V: r \wedge) \\
& \text { الفخذ . }
\end{aligned}
$$




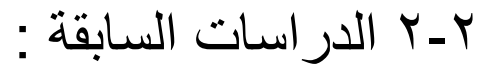

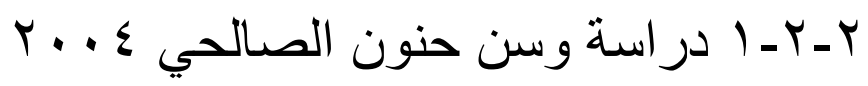

"منهج تدريبي باستخدام مؤثر النبض وتأثيره في متغيرات فسيولوجية وكيميائية وعلاقته بأداء هوني

\section{مهارات هجومية في كرة السلة"}

هدفت الدراسة الى التعرف على تأثير المنهج التدريبي على بعض فرة القدرات الفسيوكيميائية

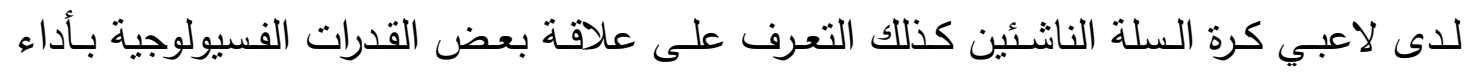

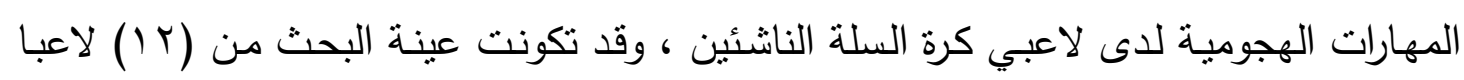

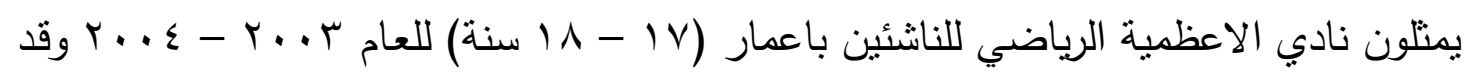

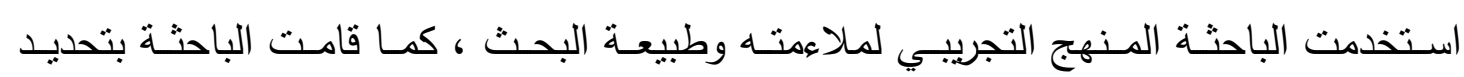

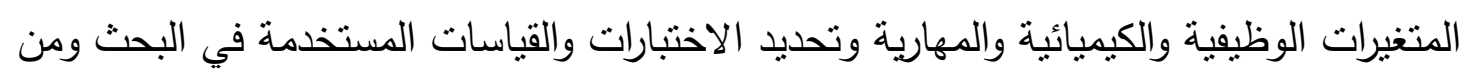

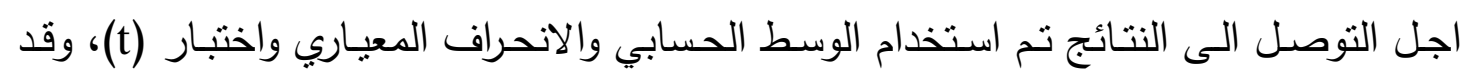

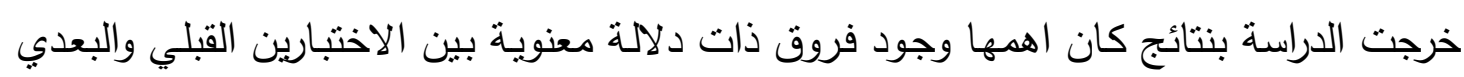

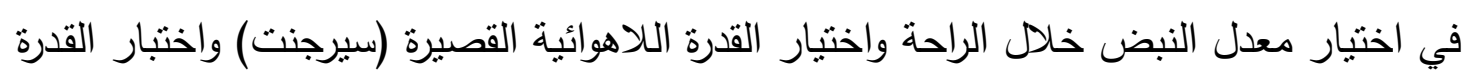
اللااوكسجينية اللاكتية (اختبار طومسون) ، كذلك وجود فروق ذات دلالة معنوية بين الاختبارين

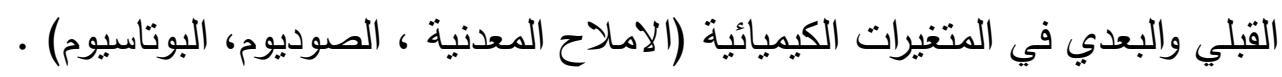

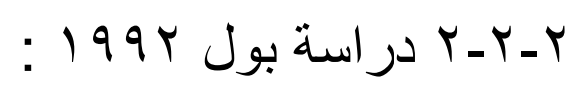

"تاثير الرقص الهوائي على مكونات الجسم والحد الاقصى لاستهلاك

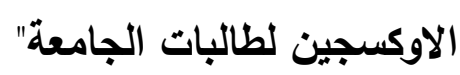

هدفت الدراسة الى التعرف على تاثير برنامج تعليمي في الرقص الهوائي على نسبة الهمهية

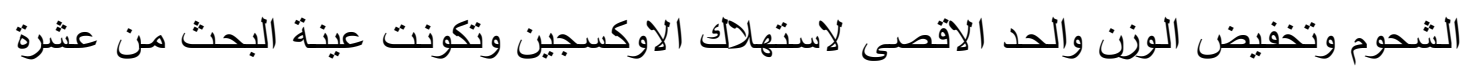

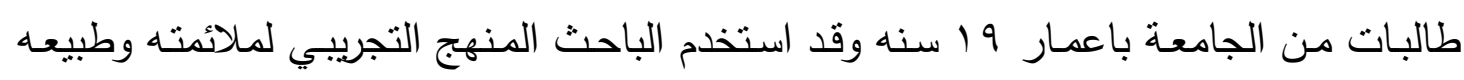

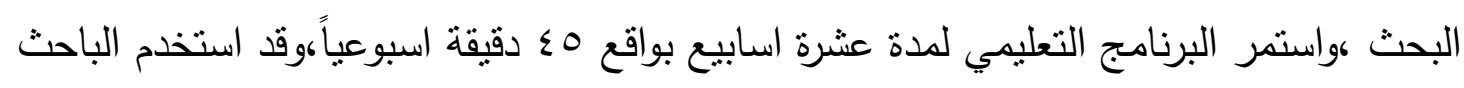

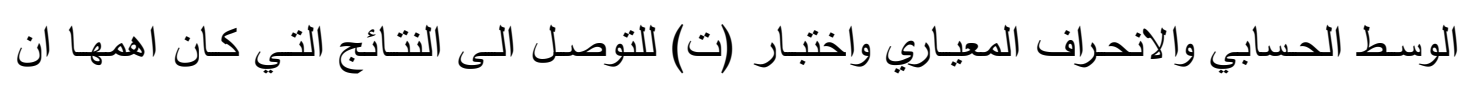
الرقص الهوائي يؤثر ايجابياً على الحد الاقصى لاستهلاك الكابل الاوكسجين. 


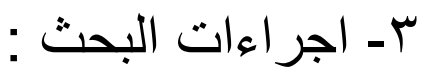

ب- ا منهج البحث : استخدمت الباحثة المنهج التجريبي لملاءمته وطبيعة البحث .

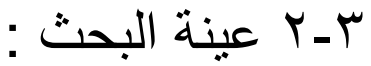

تم اختيار عينة البحث بطريقة عمدية من طالبات السنة الاولى قسم التربية الرياضية في

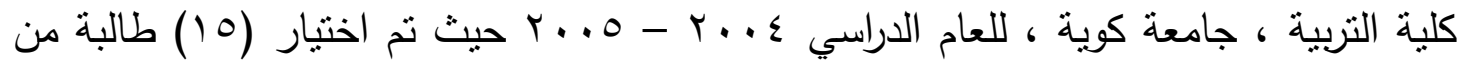
اصل (rV) طالبا وذللك لالتزامهن بالدوام وتجانسهن بالمتغيرات البدنية التي تؤثر على تعلم

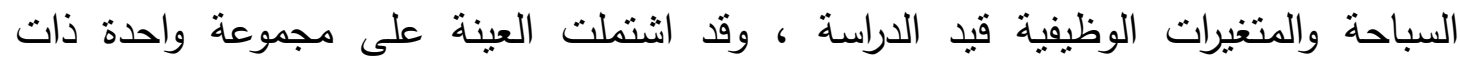

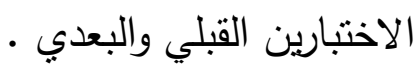

(الجدول (1)

يبين مواصفات عينة البحث

\begin{tabular}{|c|c|c|c|}
\hline العدد العد & الانحراف المعياري & الوسط الحسابي & المتغيرات \\
\hline 10 & 1 ب, سم & إ, •• 17 سم & الطول \\
\hline 10 & ( & 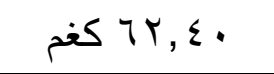 & 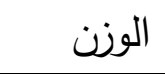 \\
\hline 10 & 1 , 1 سنة & 19,1 سنة & العمر - ال العر \\
\hline
\end{tabular}

ب-r ت تجانس عينة البحث :

على الرغم من تجانس عينة البحث كونها من فئة عمرية واحدة كذللك في مرحلة دراسية واحدة ، الا ان الباحثة لجأت الى اجراء التجانس في المتغيرات البدنية المؤثرة على السباحة لعدم

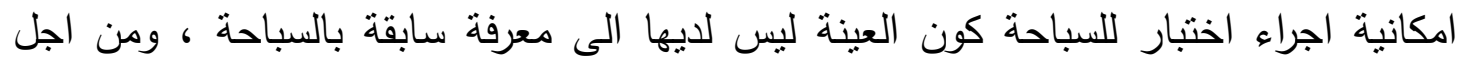

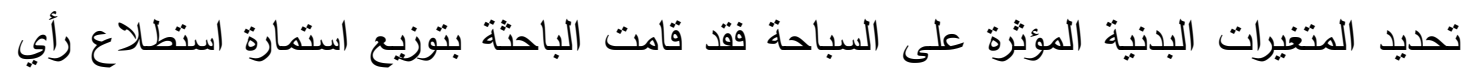

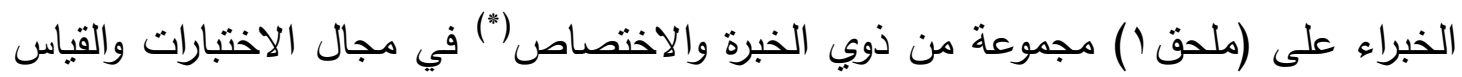

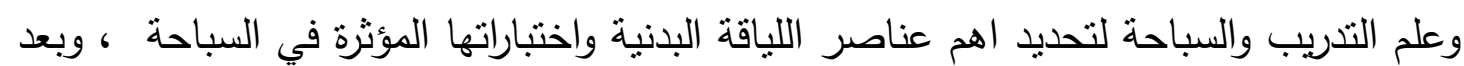
تفريغ الاستمارات الخاصة بالاستبيان تم الحصول على ثلاثة عناصر هي (مطاولة القوة لكل من

$$
\begin{aligned}
& \text { • ( أ.د. ) } \\
& \text { - أ.د. صريح عبدالكريم . } \\
& \text { - أ.د. نوري الشوك . }
\end{aligned}
$$


الذراعين والرجلين والسرعة الانتقالية ومرونة الكتفين) فضلا عن الحصول على الاختبارات الخاصه بها والجدول (r) يبين ذلك .

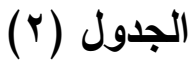

يبين الاختبارات البدنية المستخدمة والغرض منها ومصدرها

\begin{tabular}{|c|c|c|}
\hline المصدر & الغرض من الاختبار & الاختبارات البذنية \\
\hline$(11 \cdot: 11)$ & قياس مطاولة القوة للذراعين والكتقين & اختبار التعلق من وضع مد الذراعيين \\
\hline$(111: 11)$ & 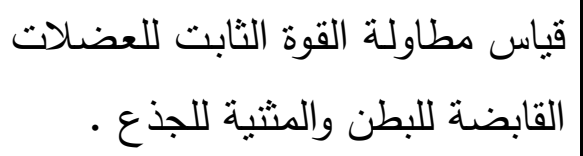 & اختبار رفع الرجلين عاليا \\
\hline$(10 V: 1)$ & | قياس السرعة الانتقالية & اختبار •0 م \\
\hline$(\mid \wedge r: Y I)$ & | قياس مرونة الكتفين & اختبار المدى الحركي للكتفين \\
\hline
\end{tabular}

تم اختبار عينة البحث في الاختبارات السابقة وبعد معالجتها احصائيا باختبار (t) للعينة

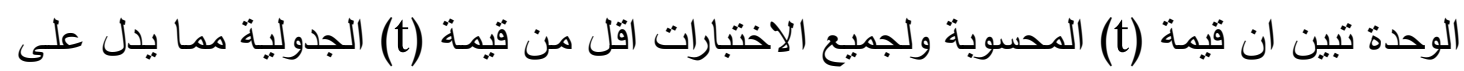
تكافؤ عينة البحث والجدول (r) بيين ذللك.

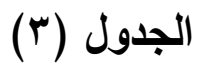

يبين الوسط الحسابي والانحراف المعياري وإختبار(ت)للاختبارات البدنية لعينة البحث

\begin{tabular}{|c|c|c|c|}
\hline قيمة ت المحسوية & الانحراف المعياري & الوسط الحسابي & الاختبارات البدنية \\
\hline VV. & $r, r r$ & $M Y, \sum T$ & اختبار التعلق من وضع مد الذراعيين/ثا \\
\hline $1, \wedge \wedge$ & 1,17 & $17, Y 7$ & اختبار رفع الرجلين عاليا /ثا \\
\hline 1,09 & or. & 7,01 & اختبار •0م م/ثا \\
\hline 1,70 & 1,17 & $0, \pi r$ & اختبار المدى الحركي للكتفين /نقطة \\
\hline
\end{tabular}

$\wedge \wedge$ 
r- الاختبار ات الفسيولوجية المستخدمة :

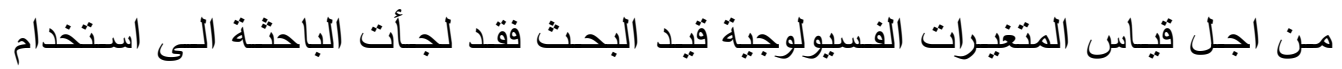
الاختبارات الاتية : (قياس معدل القلب لقياس النبض ، قياس ضغط الدم ، اختبار استراند على فئل

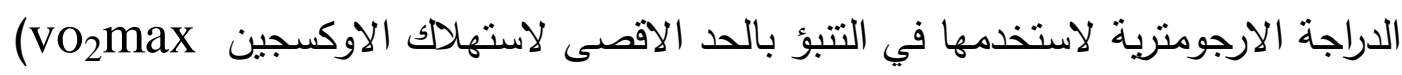
- (YMT,VV 6V $1: 19)$

بـ ـ قياس سمك الثنايا الجلدية

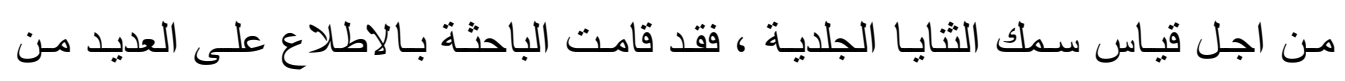

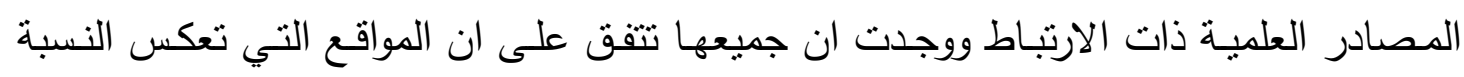

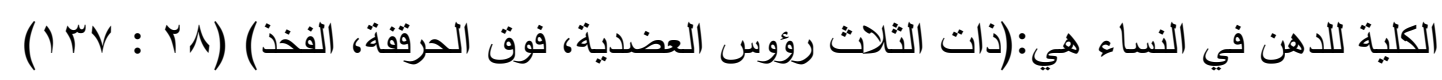

r-7 البرنامج التعليمي المقترح

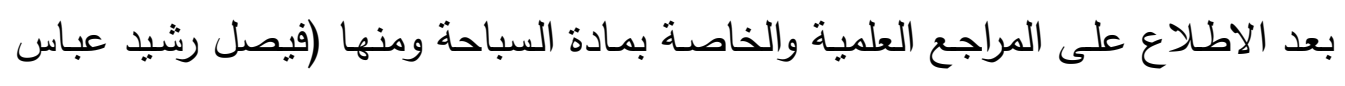

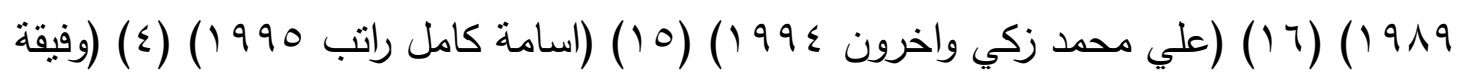

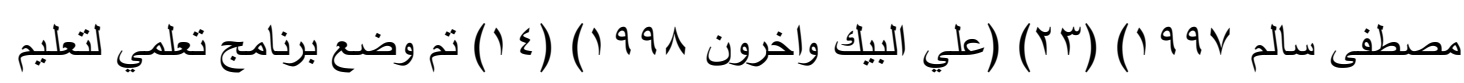

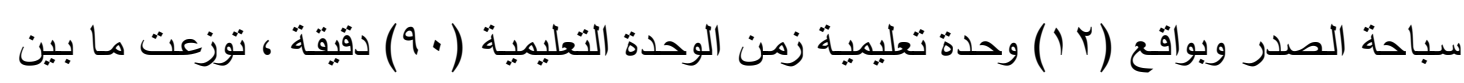

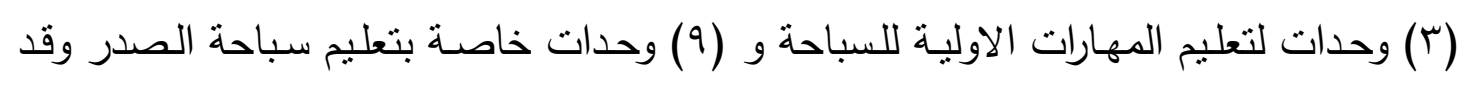

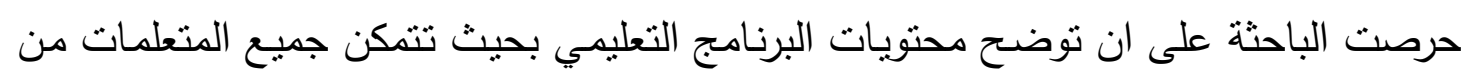

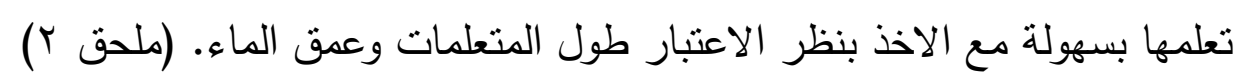

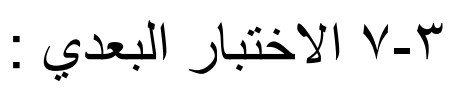

بعد تتفيذ البرنامج التعليمي وانهاء الوحدات التعليمية ، قامت الباحثة بأجراءات القياسات

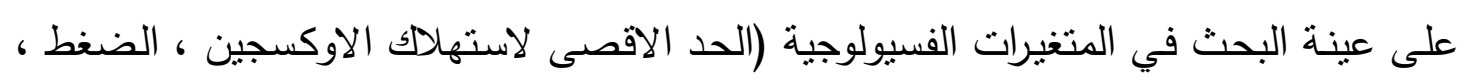

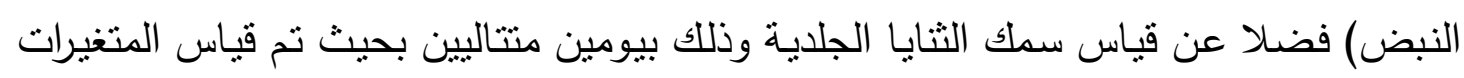

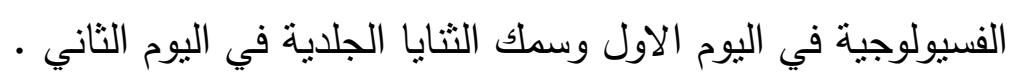

ب-1 المعالجات الاحصائية:

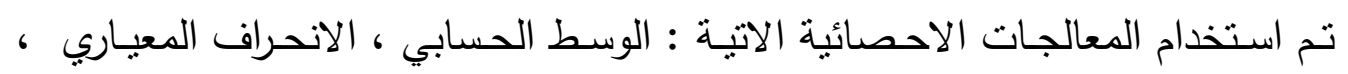

$$
(r \vee T-1 \cdot 1: r \cdot)
$$




\section{ع - عرض النتائج ومناقشتها}

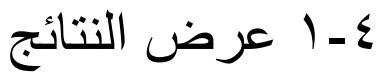

من اجل ان تتأكد الباحثة من تحقيق اهداف البحث واختبار فرضياته فقد لجأت الى الى

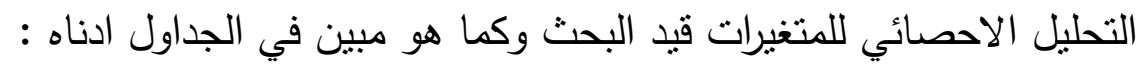

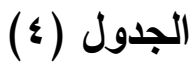

يبين الوسط الحسابي والانحراف المعياري وإختبار (t) للاختبارين القبلي والبعدي في المتغيرات الفسيولوجية لعينة البحث

\begin{tabular}{|c|c|c|c|c|c|}
\hline \multirow{2}{*}{ قالمحسوية ت } & \multicolumn{2}{|c|}{ الاختبار البعدي } & \multicolumn{2}{|c|}{ الاختبار القبلي } & \multirow{2}{*}{ 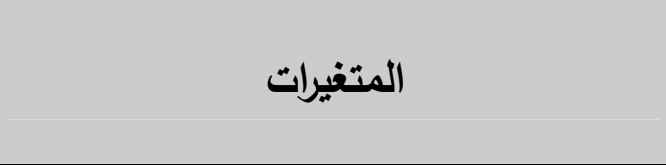 } \\
\hline & $\varepsilon \pm$ & س & $\varepsilon \pm$ & س & \\
\hline $7, r_{0}$ & .17 & $r, \wedge \varepsilon$ & 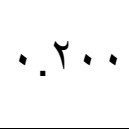 & $r, \varepsilon V$ & اختبـار الحــــالاقـــى لاسـتهلاك الاوكسجبين \\
\hline$r, V \varepsilon$ & 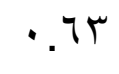 & $\mid r, \varepsilon$. & .07 & $1 \pi, 0$. & الضغط الانقباضي /ملم زئبق \\
\hline$r, 00$ & $\cdot M$ & $V, 97$ & .70 & $\wedge, 97$ & الضغط الانبساطي /ملم زئبق \\
\hline$r, 7 \varepsilon$ & 1.09 & $\uparrow \wedge, \leqslant \uparrow$ & r.r & VY,IT & قياس النبض • نبضة/دقيقة \\
\hline
\end{tabular}

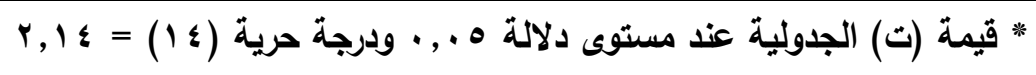

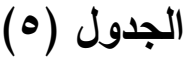

يبين الوسط الحسابي والانحراف المعياري وإختبار (t) للاختباريين القبلي والبعدي

لسمك الثنايا الجلدية لعينة البحث

\begin{tabular}{|c|c|c|c|c|c|}
\hline \multirow{2}{*}{ قالمحسوية ت } & \multicolumn{2}{|c|}{ الاختبار البعدي } & \multicolumn{2}{|c|}{ الاختبار القبلي } & \multirow{2}{*}{ المتغيرات } \\
\hline & $\varepsilon \pm$ & س & $\varepsilon \pm$ & س - ( - س & \\
\hline 1,90 & $\because \wedge \varepsilon$ & $1 \wedge, \ldots$ & $1 .+4$ & $19, \mathrm{VT}$ & ذات الثلاث رؤوس العضدية/ملم \\
\hline$r, \cdot r$ & $1 . \leqslant \pi$ & $r v, r$. & .14 & rᄉ, qr & موقع فوق الحرقفة /ملم \\
\hline $1, \wedge \mathrm{V}$ & r. .70 & $r q, v r$ & 1.09 & $\varepsilon \cdot, 7$ & موقع الفخذ /ملم \\
\hline $1, .0$ & $1 . \vee \wedge$ & $90, \mathrm{VT}$ & $1 . r$. & $99, Y \uparrow$ & النسبة الكلية للدهن /ملم \\
\hline
\end{tabular}


يتبين من الجدول (§) ان هناك فروق ذات دلالة احصائية في المتغيرات الفسيولوجية

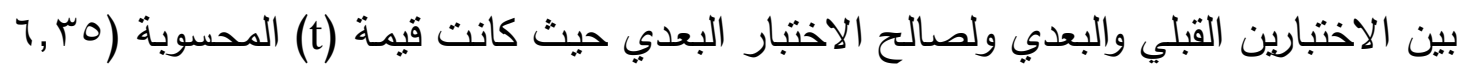

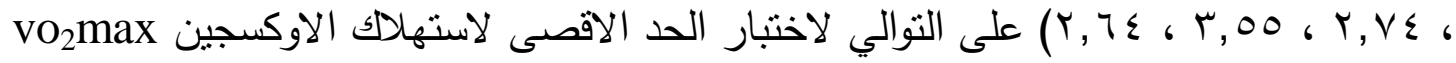

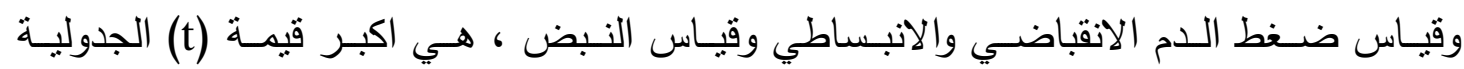

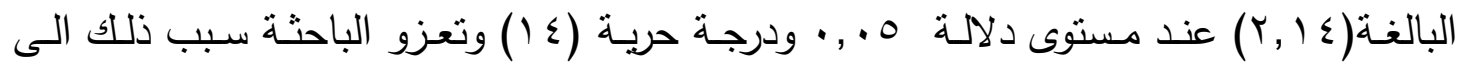
البرنامج التعليمي المقترح في السباحة والذي عمل على تحسين عمل الجهازين الدوري والتتفسي لهي ومـن ثم الى تطور الحـد الاقصى لاستهلالك الاوكسجين vo التعليمي والذي يتضمن تمرينات مكثقة تعمل على تتمية وتطوير عمل الجهاز العضلي وقابليته

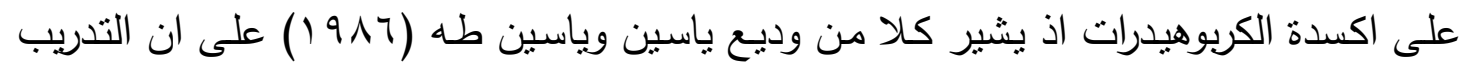

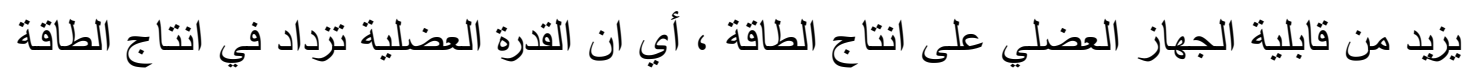

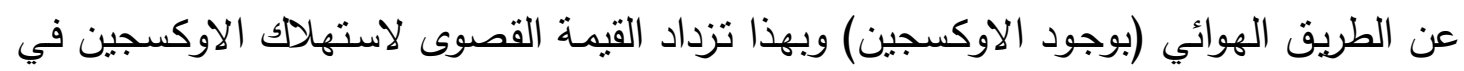

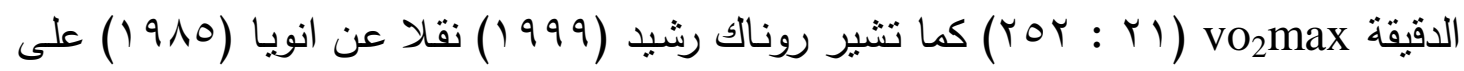

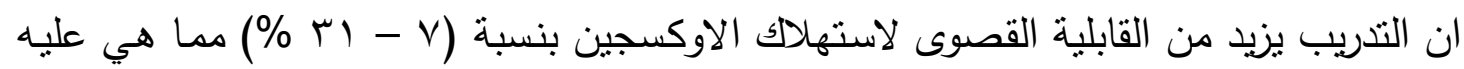

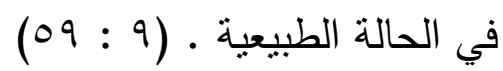

امـا فيمـا يتعلق بضغط الدم الانقباضـي والانبساطي فتعزو الباحثة سبب تحسنه الى لى

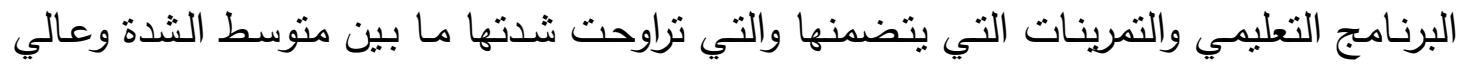

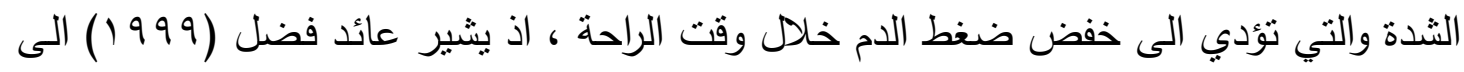

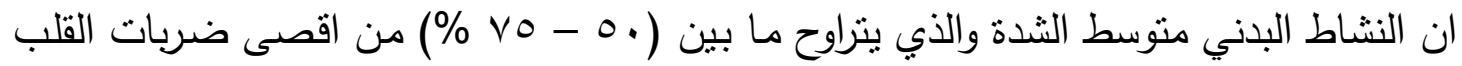

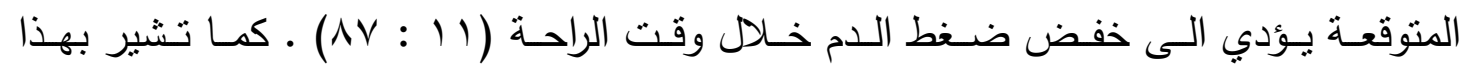

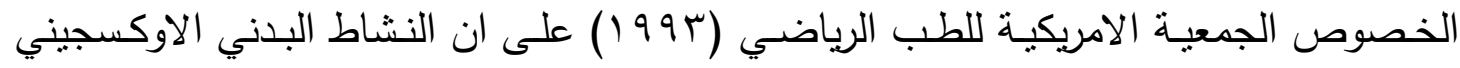

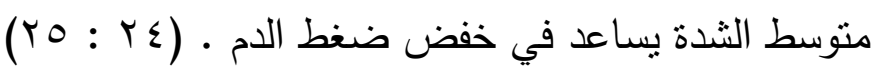
اما فيما يتعلق بالنبض فتعزو الباحثة سبب انخفاض عدد نبضات القلب وقت الراحة الى

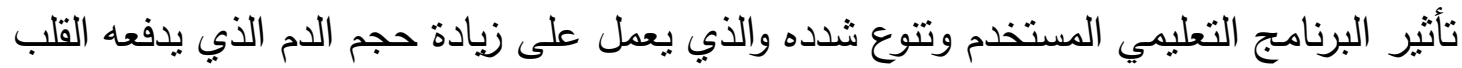
في النبضة الواحدة ومن ثم يصبح القلب اكثر كفاءة في تلبية احتياجات الجسم من الدم بعدد القل

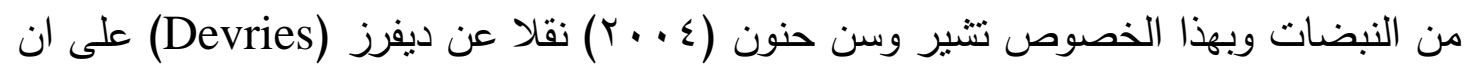
التدريب المنظم يعمل على تكيف القلب اثناء الراحة او عند اعطاء احمال تدريبية مختلفة مقارنة بأثخاص غير مدربين بشكل منتظم وذلك بسبب كمية الدم المدفوعة في الضربة الواحدة وزيادة

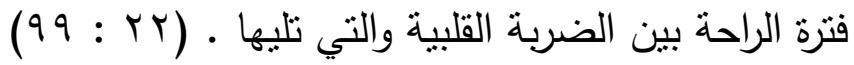


حين يتبين من الجدول (0) عدم وجود فروق بين الاختياريين القبلي والبعدي لسمك

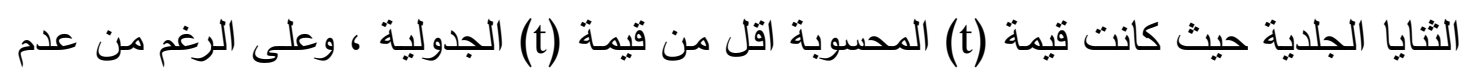

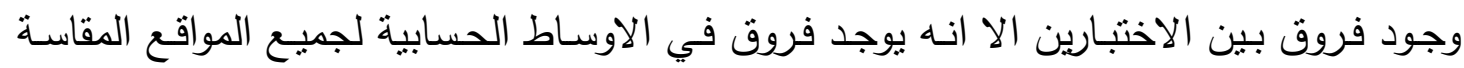

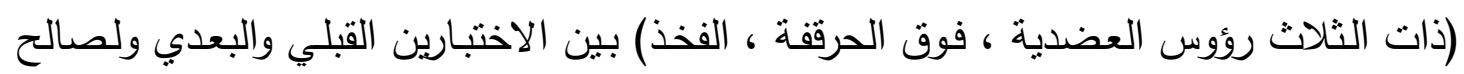
الاختبار البعدي ، وتعزو الباحثة سبب هذا الفرق في الاوساط الى البرنامج التعليمي المقترح

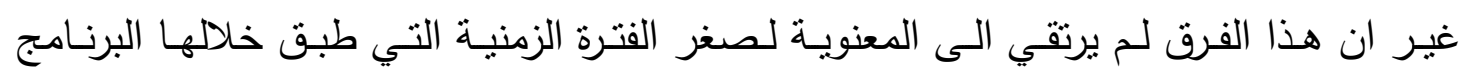
التعليمي •

\section{هـ الاستنتاجات و التوصيات 0ـ ا الاستتناجات}

من خلال النتائج التي توصلت اليها الباحثة فقد خرجت بعدد من الاستنتاجات وكما يأتي: 1. البرنامج التعليمي المقترح ذو تأثنير ايجابي على المتغيرات الفسيولوجية وسمك الثنايا الجلدية.

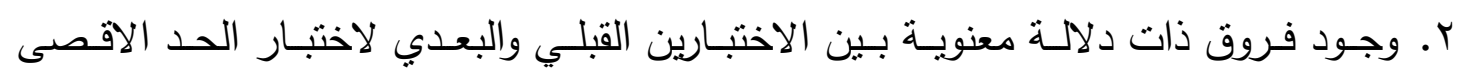
لاستهلاك الاوكسجين Vo

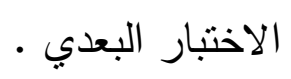

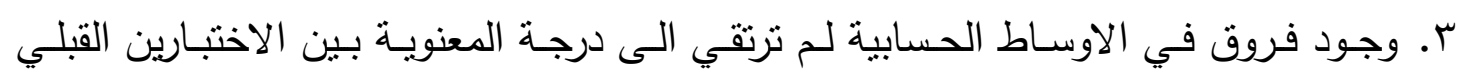

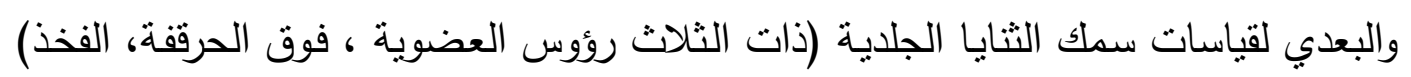

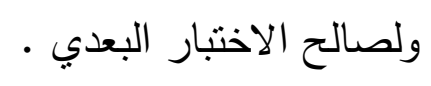

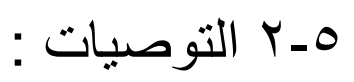

ا ـ استخدام البرنامج التعليمي المقترح لتعليم سباحة الصدر لكفاءته في تطوير وتتمية المتغيرات

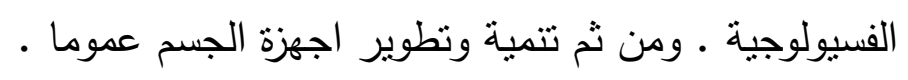

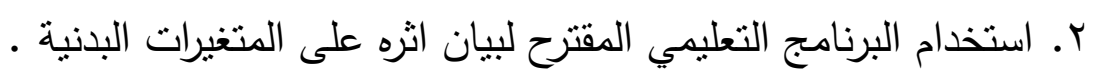

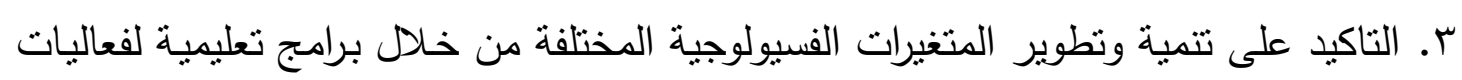

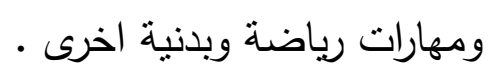

ـ. استخدام البرنامج التعليمي المقترح لبيان اثره على متغيرات فسيولوجية اخرى (مكونات الدم

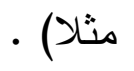
هـ التأكيد على تقليل سمك الثنايا الجلدية من خلال التركيز على التمرينات الهوائية في البرامج 


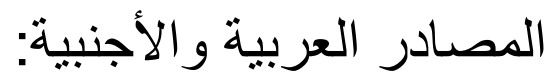

1. ابراهيم احمد سـلامة : المدخل التطبيقي للقياس في اللياقة البنيـة ، منشأة المعارف ،

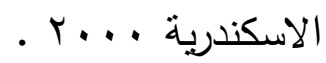

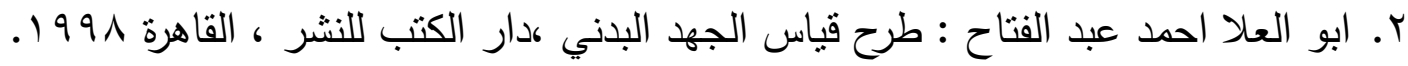

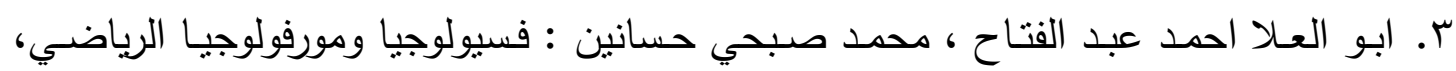

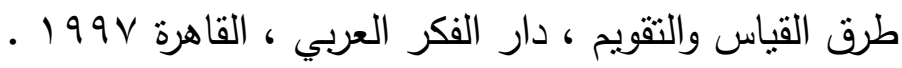

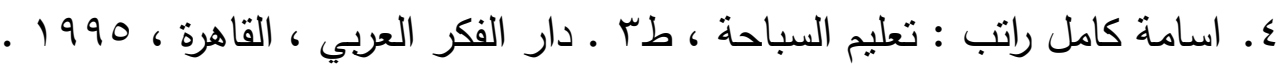

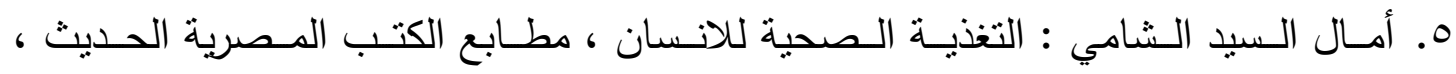
الاسكندرية، 1910. 4. بسطويسي احمد بسطويسي : اسس ونظريات التُريب الرياضي ، دار الفكر العبي ، القاهرة . r..r.

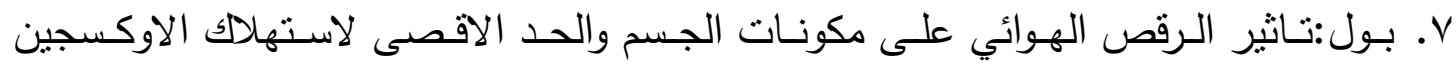

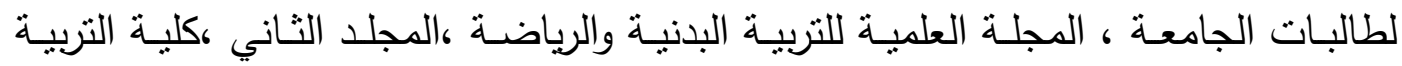

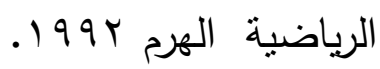
^. رافع صـالح فتحي : تطور العمل الوظيفي والصفات القياسية للقلب بتأثير المطاولـة ،

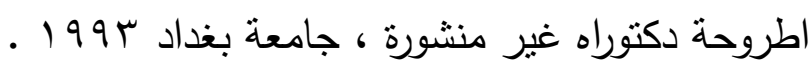

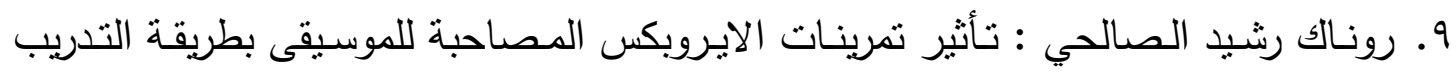

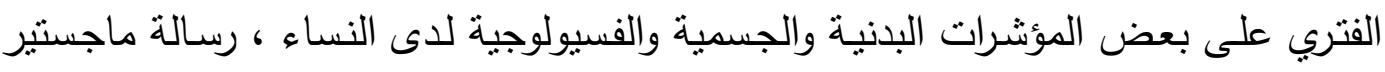

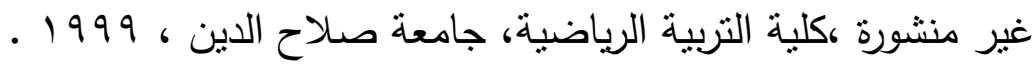

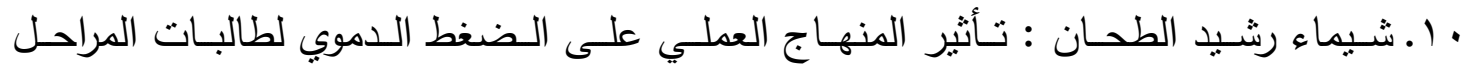

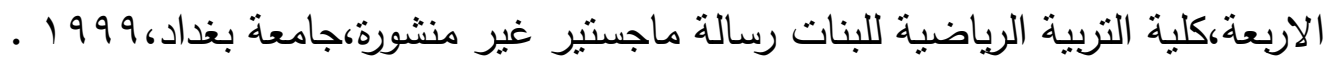

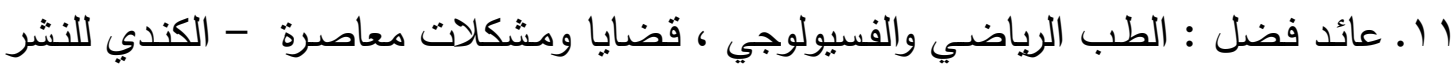

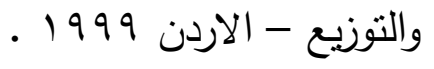
rا. عادل عبد العال : التدريب الرياضي والتكامل بين النظرية والتطبيق ، طا ـ مركز الكتاب

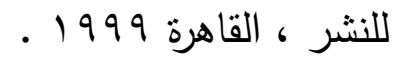
با . عبدا لمنعم مصطفى : أمراض القلب والأوعية الدموية ، طا ، المؤسسة العربية للاراسة

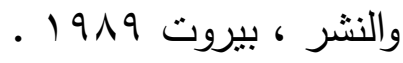
ع ا ـ علي فهمي البيك واخرون : اتجاهات حديثة في تعليم السباحة (الزحف - الظهر ) ومنشأة

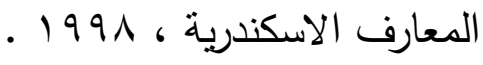


1 ـ علي محمد زكي واخرون : السباحة - تكنيك - تعليم - تدريب - انقاذ ، دار الفكر العربي

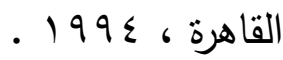

7 ا ـ فيصل رشيد عياش : رياضة السباحة ، بيت الحكمة ، جامعة بغداد ، 1919 .

V ا ـ محمد حسن علاوي ، ابو العلا احمد عبد الفتاح : فسيولوجيا التدريب الرياضي ، دار الفكر

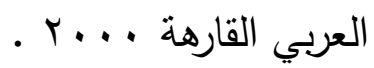

1 ا ـ محمد حسن عـلاوي ، محمد نصر الدين رضـوان : اختبـارات الاداء الحركي ، دار الفكر

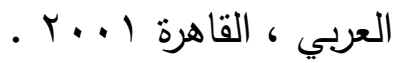

9 1 ـ محمد نصر الدين رضـوان : طرق قياس الجهد البدني في الرياضـة ، طا، مركز الكتاب

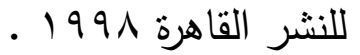

• ץ. وديع ياسين ، حسن محمد عبد : التطبيقات الاحصائية في بحوث الرباضة الكتب للطباعة والنشر ، جامعة الموصل 1997 . 197

ا ب. وديـع ياسـين ، ياسـين طـه : الاعداد البدني للنساء ، مديربـة دار الكتب للطباعـة والنشر جامعة الموصل ،

r r . وسن حنون الصالحي : منهج تدريبي باستخدام مؤشر النبض وتأثثره في متغيرات فسيولوجية وكيميائية وعلاقته بأداء مهارات هجوميـة في كرة السلة ، أطروحة دكتوراه غير منشورة ،

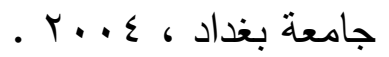
بr. وفيقة مصطفى سـالم : الرياضـات المائيـة اهدافها - تدريسها - اسـس تدريبها - أسـاليب

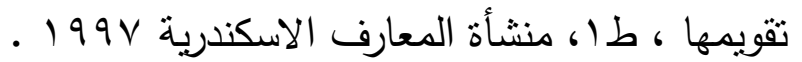

24. American College of sports 1993 : Medicine Physical activity Physical fitness and pretension stand medsci sport exercise.

25. Christine Lwells. 1991 : Differences between male \& female athlet's in woman sport \& performance human kinetics book. U.K.

26. Derries Herbert A \& Hours Terry J. 1994 : Physiology of Exercise $5^{\text {th }}$ Ed. Human publishers WcB brown bench mark publishers.

27. Edward , I. Howley \& B. Donfrank 1992 : Health fitness $3^{\text {rd }}$ Ed human kinetics champing illiois. USA.

28. Hoeger W.W. K. \& S.A. Hoeger 1995 : Lifetime Physical fitness and Wellness : A personalized, Englewood Co. Morton Publishing. 


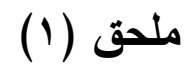

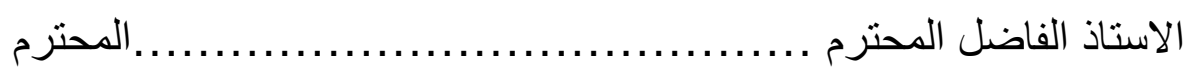

تحية طيبة ....

في النية اجراء دراسة بعنوان (تأثثر برنامج تعليمي مقترح في السباحة لبعض المتغيرات

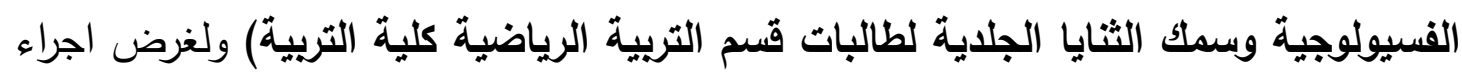
عملية التتجانس بين عينة البحث ونظرا لما تتمتعون به من خبرة في هذا المجال يرجى بيان

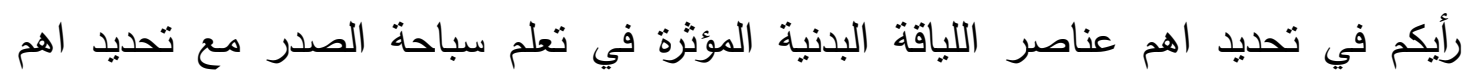
الاختبارات الملائمة لها لـ الهم

مع التقدير

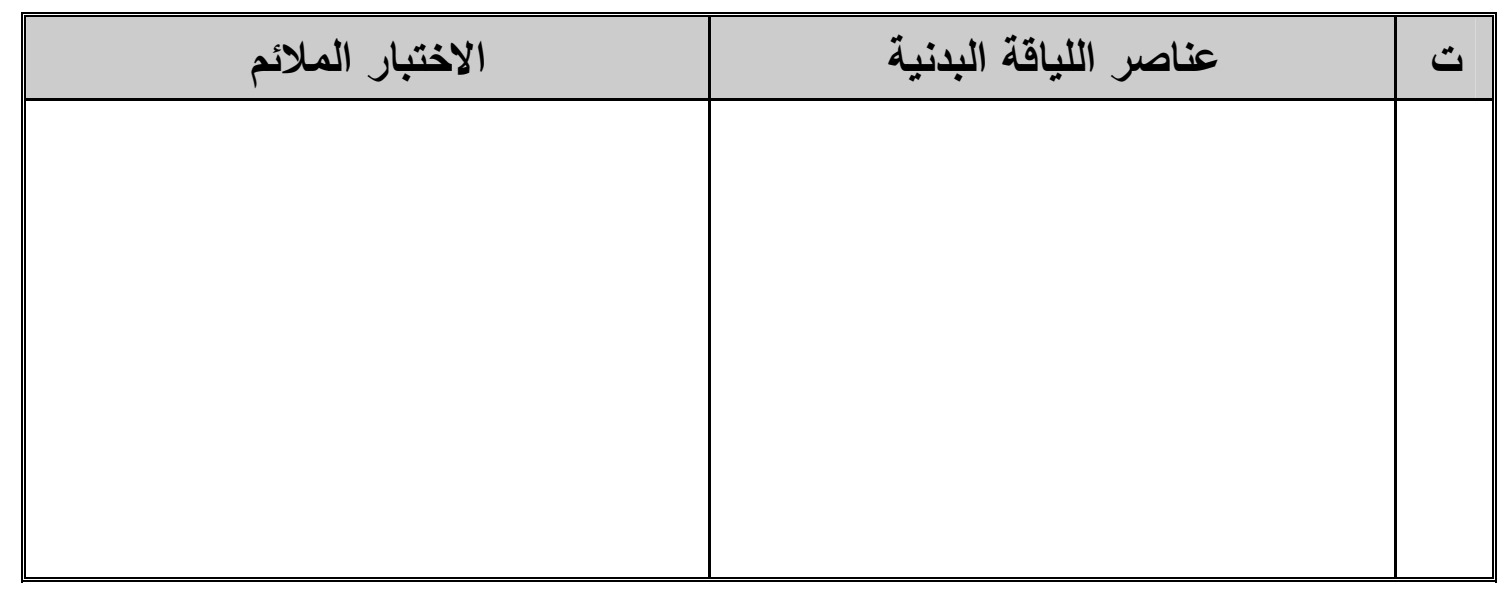

التوقيع :

: الاسم :

الدرجة العلمية : - 2 - (الاسم

الباحثة 
الملحق (r)

\section{نموذج لوحدة تعليمية}

الهذف التعليمي : التعود والثقة ميع الماء

الجزء التطبيقي : هه دقيقة

\begin{tabular}{|c|c|c|c|c|c|c|c|c|c|c|}
\hline 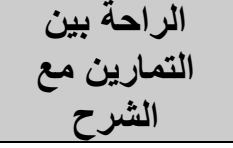 & التمرين & للتمرين الواحد الراحة & الأراحة بين & زالدن ادوات & زمن التمرين & عدد الدورات & التكرارات & \multicolumn{2}{|l|}{ التمرين } & التعليمية \\
\hline آل د د راحة شرح الثاني & • & Oد & اد & r. . & ه ثا. & 7 & . ع مرة & الماء بالرجلين حافة السبح تحريك & الاول & \multirow[t]{5}{*}{ الاولى } \\
\hline التمرين الثالثة شرح & T د & مثا. & ا ا ثا & Fr.. & ه ثا. & 7 & 1 & واحدة / و ا مسك حافة المسبح بيد & الثاني & \\
\hline التمرين الرة شرح & T د & ه ثان & ا ا ثا & r ستا. & ه & 7 & 1 & 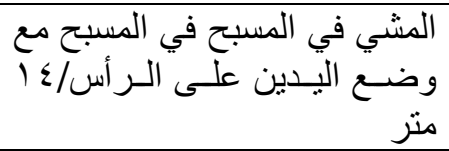 & الثالث & \\
\hline \multirow[t]{4}{*}{ 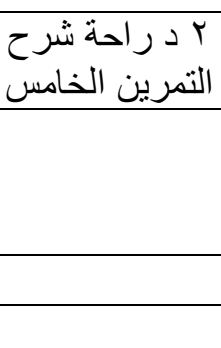 } & T د & ه ثان & ا ا ثا & שץ". & ه० & 7 & 1 & 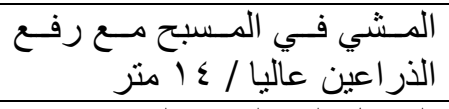 & الر ابع & \\
\hline & 219 & Tr & ו & د 17 & $0 \leqslant$ & $\varepsilon$ & r مرة & 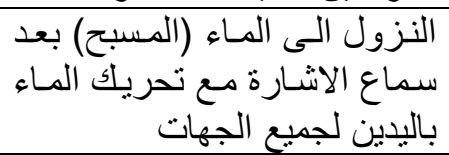 & الخامس & \\
\hline & 01 & $د \leqslant V$ & & & & & & & المجموع & \\
\hline & & 000 & & & & & & & الكلي & \\
\hline
\end{tabular}

